Continued from page 9

churches support a full appeal as of right. A minority, while supporting the full right of appeal for most appellants, favour the right of leave to appeal for a few carefully defined types of appellant.

Some, among them the Representative for the United Nations High Commissioner for Refugees, favour a centralized appeal, noting that in a regional process lack of a review of the reasons for denying claims would entail inconsistencies in the appeal country-wide when there is a need to create a jurisprudence.

Costs are a legitimate consideration. However, most would find a strong appeal essential irrespective of cost in such an important matter as refugee determination. The additional cost of such an appeal and the additional time could be quite modest. All things considered, it is difficult to imagine that the new procedure with appropriate appeal could be any more costly than the present procedures.

\section{Conclusion}

There has been considerable progress towards a consensus. The consensus is shared not only among the non-governmental community but with the Standing Committee of Parliament. The appeal is the major outstanding issue to be resolved between non-governmental groups and the Standing Committee. In this outstanding area, there remains real concern that an adequate appeal will not be provided.

An examination of summary reviews of refugee determination in several countries ("Refugee Status Decision-Making: The Systems in Ten Countries", Avery, Stanford Journal of International Law, Summer 1983; or The Refugee in International Law, Goodwin-Gill, Oxford 1985) reveals that the proposed refugee determination, plus an appeal with the features proposed above, would be among the best in the world. Such a refugee determination procedure would mark Canada's coming of age in all aspects of refugee concerns. The procedure would be a statement to the international community of Canada's commitment to the international humanitarian instruments. It would be a signal of justice with compassion to refugees in need of protection in Canada.

Tom Clark is the Co-ordinator of the Inter-Church Committee for Refugees.

\title{
Racism in Canadian Immigration Policy
}

\author{
Part Two: The Present
}

We now have a sophisticated enough knowledge of racial discrimination to know that there can be racial discrimination in fact without racial discrimination in form. The Immigration Act may not be intentionally discriminatory. The question whether it generates systemic discrimination is an open one. In looking at the question, I want to examine four topics - visitor's visas, delays, the points system, and refugees.

The general rule in the Immigration Act is that everyone must have a visa issued at a Canadian immigration post abroad before coming to Canada. The Cabinet, the Governor in Council, has the power to make exceptions to this rule.

The regulations contain all sorts of exceptions. Citizens of 77 countries do not need visas to enter as visitors. For the U.S. the arrangement is particularly generous. U.S. citizens, as well as permanent residents, do not need visas. People from these countries can appear at the border and get a visitor's permit.

Theoretically it is easier to obtain a visitor's permit at the border than a visitor's visa abroad. Once a person has made a long trip to Canada, it is much more difficult for an immigration officer to deny entry than if the person were still in his home country. Denial of entry may mean deportation, with extra cost to the government. As well, delays are shorter. A person granted a visitor's permit at the border usually has to wait only a few minutes in a queue. A person granted a visitor's visa at a Canadian post abroad typically has to wait months. Imposing a visa requirement, or more accurately, removing the visa exception makes visiting more difficult.

For a select group of immigrants visiting is particularly difficult. Citizens of 14 countries are required to obtain visas even if they are in Canada in transit-even if they never leave the airport or the plane. People from these countries are prohibited from passing through Canada en route to another destination unless they obtain a Canadian visa abroad.

The reason why a visa is required, in general, is that citizens of these countries have been abusing the visitor's permit system.
Immigration has found that a significant number of individuals with visitor's permits have overstayed their visits. Enforcement action has been necessary to remove them from Canada. A visa requirement is intended to cut down on this abuse.

In my opinion, it is inherently unfair to anyone that he be told he must get a visa before he enters Canada because Immigration believes, on the basis of his nationality, that he may overstay a visitor's permit.

The Canadian Charter of Rights and Freedoms guarantees the legal benefit of the law without discrimination based on national or ethnic origin. To say that nationals of one country require visas and nationals of another do not is discrimination based on national origin. The Charter guarantee applies to "every individual". It is not limited to Canadian citizens and permanent residents, as are other Charter guarantees. The Supreme Court of Canada has already said that another Charter guarantee, about fundamental justice, can apply to illegal aliens in Canada or at a port of entry who claim refugee status. This Charter guarantee, as well, would apply to persons at a port of entry.

Right now a person from a country with a visa requirement can be ordered deported if he appears at a Canadian port of entry without a visa. In my belief, a person ordered deported on this basis could challenge the deportation under the Charter.

There is yet another problem for visitors and that is a problem faced by those who come from countries for which visas are not required. Foreigners who come to Canada from countries for which no visa is required are subject to examination as to whether they are genuine visitors. Not every visitor is examined. Examination is selective. There is a common feeling that this selection is discriminatory.

The Parliamentary Committee on Visible Minorities that produced the report "Equality Now" noted that rightly or wrongly there is a widespread perception among visible minorities that treatment of minorities at the border discriminates on the basis of race or ethnic origin. In the words of one witness, "Turbans at- 
tract attention." The Committee recommended that Employment and Immigration Canada should take appropriate steps to ensure that members of visible minorities are not unduly singled out for unusual immigration procedures and that all such procedures are adequately explained to arriving persons and their awating relatives and friends.

The response of the Government to that recommendation was that it was well aware of the perception that visible minorities are unduly singled out for a more intensive interview when attempting to come into Canada. The Government committed itself to developing a cross cultural training programme for its officers as well as greater liaison with ethnic communities.

The second contemporary question I want to look at is delays. The law's delay is nothing as compared to the bureaucrat's delay. What is particularly worrying is the maldistribution of the delay. For Canadian visa offices in some parts of the world, delays are relatively short. In other parts of the world, delays are excruciatingly long.

A table published in 1982 by the Recruitment and Selection Branch of the Canada Employment and Immigration Commission for family class applications gives some idea of the dimension of the problem. For instance, in the third quarter of 1982 the mean processing time from application received to final disposition in London was 84 days, in Birmingham 93 days, in Sydney 120 days, and in New York 176 days. At the other end of the scale, the mean processing time in Manila was 380 days, in New Delhi 324 days, in Port of Spain 303 days, and in Hong Kong 289 days. In other words, an application took four and one half times as long to process in the Philippines as it did in the U.K.

These figures are three years old. But I am a lawyer in immigration practice in Winnipeg, and it is my experience that these variations still exist today. I cannot tell you what mean processing times are. But I can say there are substantial variations in processing times among posts abroad.

Another related problem is office distribution. In 1983, when we received over 7,800 landed immigrants from India, we had only one visa office in New Delhi. Yet distances are large, and transportation is inefficient, time consuming and expensive. And interview requirements are common. In the Philippines, from which we received 4,600 immigrants again from a large territory - there was only one immigration office, in Manila.

In the United Kingdom, from which we received 5,700 immigrants, we had three visa offices, in Glasgow, Birmingham and London. In France, from which we received 1,500 immigrants we had three visa offices, in Marseilles, Bordeaux and Paris. In the United States from which we received 7,000 immigrants, we had eleven visa offices.

In other words, the intake from India and the U.S. was about the same, with India being a little bit higher. Yet we had eleven times as many offices in the U.S. as in India. It is little wonder that processing delays in India are greater than in the U.S.

The Parliamentary Committee on Visible Minorities dealt with this issue as well. The Government of Canada attributed the lengthy delays in some countries primarily to factors such as the lack of reliable systems of record keeping in the country of origin. However, as the maldistribution of offices shows, that cannot be the whole explanation.

The Committee recommended that the Government conduct a general review of its policy with regard to location of offices and procedures for processing applications. The Government, in its response, said it was opening seven new points of service in existing Canadian missions in developing countries. The Government said it will closely monitor processing times of posts.

Thirdly, there is the points system. Independent immigrants are admitted to Canada depending on how many points they receive. Points vary with skill, education, experience and training. Right now, as well, it is essential to have a job for which no Canadian is available, or buy a business that employs at least one Canadian, or start or buy a business for which there is significant demand.

A system like that is almost designed to generate discrimination by effect. If an employer had a system like that in place, he would almost certainly need an affirmative action programme coupled with it in order to overcome its discriminatory effect. Needless to say, for immigration there is no such thing as an affirmative action programme.

Whether the point system imposes systematic discrimination can only be tested for certain when there is the appropriate collection of statistical data. If we exclude refugees and the family class, and look just at all those who came in as independent immigrants, is it harder for a black to meet the points requirements than a white? Is it harder for an Indian to meet the requirements than an American? In the absence of data, we cannot make any conclusions with certainty. However, I cannot help but suspect that the points system does work in favour of some racial groups and against other racial groups. If that is so, we need to do something about it.

The final point I want to make has to do with refugees. There is not reason to believe we have in immigration today the rabid bigotry that motivated it during the time of Fred Blair. Yet there are preferences. There is unfairness.

The two are closely linked. A preference, in itself, is unobjectionable if the system as a whole is fair. Once the system as a whole is unfair, giving preference becomes discriminatory. I do not intend to go into why I think the Canadian refugee determination system is unfair.

Suffice it to say for now that at least on one point, the need for oral hearings, the Supreme Court of Canada has spoken. The Court has held the whole refugee determination procedure unconstitutional, in violation of the Charter guarantee of fundamental justice and the Bill of Rights guarantee of the right to a fair hearing, because there is no right to an oral hearing in the system.

An unfair system means inaccurate results. Genuine refugees in Canada are being denied refugee status. And yet, there are all these preferences. There is the selfexiled class. Citizens of Eastern Europe do not have to show they are refugees. All they have to show is that they are outside Canada, outside their country of citizenship, are unwilling or unable to return and will be able to become successfully established in Canada.

There is the Indochinese designated class. Citizens of the countries of Indochina have basically the same advantageous rules as the citizens of countries of Eastern Europe.

There is the Political Prisoners and Oppressed Persons designated class. They, too, do not have to meet the refugee definition. They do not have to be outside their country of origin. They must show

Continued... 


\section{Continued from page 11}

they have been subject to some form of penal control for political expression, and are able to become successfully established in Canada. Four Latin American countries and Poland are in this class.

In addition to the designated classes, there are special procedures for persons from countries experiencing adverse domestic events. There are currently nine countries for which special procedures are in effect. The procedures vary from country to country, but typically they do not permit deportation back to the country of origin. Relatives not in the family class may sponsor persons from these countries.

I do not suggest that these procedures cease. On the contrary, when the government tried to impose more stringent regulations on the self-exiled class, to make it more difficult to defect from Eastern Europe, I objected. What I do say is that these special procedures point out the importance of making our refugee determination procedure work fairly. With a fair refugee determination procedure, some of these special rules would not be necessary. The people who are taking advantage of them could simply claim refugee status.

\section{Conclusion}

Canada has come from being a country, in the space of a few decades, where racism was prevalent to a country where respect for human rights is universally accepted, at least in principle. However, there is a big step from principle to practice. The goal of racial equality is stated in our Immigration Act and in our Charter. To reach that goal, there is still work to do.

David Matas, a Winnipeg lawyer, is Legal Counsel to the League for Human Rights of B'nai Brith Canada. The first part of this paper was published in our last issue of Refuge (December 1985).

\section{Refugee or Asylum: A Choice for Canada?}

\section{An International Symposium, May 27-30, 1986}

The Refugee Documentation Project of York University will host an international symposium, Refuge or Asylum: A Choice for Canada? at Glendon College, York University, Tuesday through Friday, May 27-30, 1986.

The Organizing Committee, Professors Michael Lanphier (Sociology, York University) and Howard Adelman (Philosophy, York University) and Dr. Lubomyr Luciuk (Geography, University of Toronto), have invited scholars, representatives of governments and non-governmental organizations from Europe and North America to present research papers and to guide seminar sessions on an integrated set of topics relating asylum and refuge as two types of resolutions for involuntary migrants.

This symposium highlights a number of issues arising in policy formulation by governments, especially the Canadian government, and non-governmental organizations with respect to contemporary refugee movements, pertinent ethnocultural history, policy of multi-culturalism and resettlement activities.

In that context, however, it brings forward the status of political asylum, which has to date not received appropriate systematic attention in conceptualization about the refugee experience. Although considered by policy makers in the Canadian government, asylum has not been acknowledged as a viable alternative to refugee status for involuntary migrants arriving in Canada.

This symposium draws attention to the policies and practices of refugee recognition, eligibility determination, and selec- tion. This focus is highlighted by comparison of the Canadian experience with those in the United States and European receiving countries.

Specific case materials will be presented by specialists in the respective fields. The experience of resettlement and return of refugees from Latin America will receive special attention in light of Canada's important involvement with that area.

The symposium attempts to bring a more common level of discourse and exchange between government and NGOs. The complementary nature of their contributions will be further mediated by the role of academic intervention, which attempts order and focuses upon the process of creating this order, as prerequisite to the realization of operational goals.

The organizing committee notes that while a symposium may be a short-lived event, the products of it are otherwise. Personal acquaintances among members of varied professional backgrounds and interests can be made and renewed. A symposium is an excellent and productive occasion for exchange to proceed from its commencement there. The proceedings will be edited by the three collaborators (Lanphier, Adelman, Luciuk) and Alex Zisman, Conference Co-ordinator, for publication as a scholarly book, tentatively to be given the same title as the symposium.

For further information and registration, contact the Refugee Documentation Project, 241 H Administrative Studies Building, York University, 4700 Keele Street, North York, Ontario M3J 1P3. 